\title{
Z merilnikom pospeška izmerjena gibalna aktivnost in gibalna neaktivnost otrok med prvim in tretjim letom starosti
}

\author{
Tadeja Volmut \\ Univerza na Primorskem \\ tadeja.volmut@pef.upr.si
}

Cilj prispevka je preučiti gibalno aktivnost in neaktivnost otrok med prvim in tretjim letom starosti, primerjati med vrtčevskim in izvenvrtčevskim časom, med tednom in koncem tedna ter preučiti povezanost znotrajdnevne in mednevne variabilnosti gibalne aktivnosti. Štiriindvajset otrok je merilnik pospeška nosilo pet zaporednih dni. Primerjali smo fenotipe intenzivnosti gibalne aktivnosti $v$ času vrtca in po njem ter med tednom in koncem tedna. Otroci so v povprečju dosegli $571 \pm 200$ sunkov na minuto, od tega so bili gibalno neaktivni $389 \pm 43$ minut, $v$ srednji in visoki intenzivnosti gibalne aktivnosti $71 \pm 25$ minut. Med tednom so deležni $4 \%$ več gibalne neaktivnosti $(p=0,017 ; E S=$ $0,57)$ in $3 \%$ manj nizke intenzivnosti $(p=0,002 ; E S=0,75)$ kot med koncem tedna. $V$ času po vrtcu dosegajo $41 \%$ večjo celotno gibalno aktivnost $(p=0,026$; $E S=1,16)$, za $8 \%$ manj gibalne neaktivnosti $(p<0,001 ; E S=1,00)$, za $6 \%$ več nizke intenzivnosti $(p<0,001 ; E S=1,20)$ ter za $2 \%$ več srednje in visoke intenzivnosti gibalne aktivnosti ( $p=0,024 ; E S=0,50)$. Obstaja povezanost celotne gibalne aktivnosti med tednom in koncem tedna $(r=0,688 ; p<0,001)$ ter med vrtčevskim in izvenvrtčevskim časom $(r=0,448 ; p=0,028)$. Študija prinaša pomembne podatke o gibalni aktivnosti najmlajših vrtčevskih otrok, ki nakazujejo povezave gibalne aktivnosti v različnih obdobjih dneva in med dnevi, kar je potrebno upoštevati pri zasnovi gibalnih programov otrok.

Ključne besede: merilnik pospeška, vrtec, teden, konec tedna, dopodne, popoldne

\begin{abstract}
Uvod
Predšolsko obdobje je eno izmed pomembnih obdobji, v katerem se oblikujejo gibalne in sedentarne navade (Janz, Burns in Levy 2005; Certain in Kahn 2002). Redna gibalna aktivnost ugodno vpliva na gibalni, mišično-skeletni in psiho-socialni razvoj predšolskih otrok (Timmons, Naylor in Pfeiffer 2007), poleg tega zmanjša tveganje za številne bolezni, kot so srčno-žilne bolezni (Vale idr. 2015), debelost (Reilly 2008), sladkorna bolezen tipa 2, osteoporoza, debelost ter nekatere oblike raka (Blair, Cheng in Holder 2001; Kriska idr. 2003). Redna gibalna aktivnost $v$ različnih oblikah je pomembna tudi za razvoj in
\end{abstract}


ohranjanje potrebne ravni gibalnih sposobnosti in oblikovanje takšnih navad ter vedenjskih vzorcev, ki zagotavljajo redno gibalno/športno aktivnost v vseh življenjskih obdobjih (Riddoch idr. 2004; Pišot in Planinšec 2005). Na drugi strani pa je povečana količina sedentarnih navad povezana $z$ neugodnimi psihosocialnim zdravjem, kognitivnim in gibalnim razvojem ter debelostjo predšolskih otrok (LeBlanc idr. 2012).

Strokovnjaki iz različnih držav (Tremblay idr. 2012; Department of Health and Aging 2010; National Association of Sport and Physical Education 2009) so oblikovali okvirna priporočila gibalne aktivnosti otrok do petega leta starosti. Večina teh priporoča, da naj bodo predšolski otroci dnevno gibalno aktivni najmanj 90 do 180 minut $v$ različnih fenotipih intenzivnosti gibalne aktivnosti. Ameriško združenje za šport in športno vzgojo (National Association of Sport and Physical Education 2009), za otroke med prvim in tretjim letom starosti, priporoča, da so gibalno aktivni najmanj 30 minut na dan v organizirani vadbi ter 60 minut in več $v$ neorganizirani. Poudarjajo tudi, da naj mlajši predšolski otroci ne preživijo sedentarno več kot 60 minut strnjeno, razen takrat, ko spijo. Kanadske smernice za omejevanje gibalne neaktivnosti (Canadian Society of Exercise Physiology 2015) celo priporočajo, da naj otroci do drugega leta starosti ne preživljajo svojega prostega časa pred televizijskimi ekrani, medtem ko naj ga otroci med drugim in četrtim letom največ eno uro dnevno.

V zadnjem desetletju raziskovalci veliko pozornost posvečajo objektivnemu merjenju in preučevanju gibalne aktivnosti in gibalne neaktivnosti predšolskih otrok, vendar moramo poudariti, da so študije, ki preučujejo gibalno aktivnost in gibalno neaktivnost otrok med prvim in tretjim letom, zelo redke (Cardon, Van Cauwenberghe in De Bourdeaudhuij 2011). Rezultati študij kažejo, da so vsi predšolski otroci čez dan deležni predvsem nizke intenzivnosti, ${ }^{1}$ velike količine gibalne neaktivnosti ${ }^{2}$ in nizke količine srednje ${ }^{3}$ ter visoke ${ }^{4}$ intenzivnosti gibalne aktivnosti (Aadland in Johannessen 2015; Van Cauwenberghe idr. 2012; Reilly 2008; Tucker 2008; Kuzik idr. 2015; Johanssson idr. 2015; Carson idr. 2019). P. Tucker (2008) v svoji pregledni študiji navaja, da je le polovica otrok med drugim in šestim letom starosti deležna vsaj 60minutne gibalne aktivnosti na dan ter da le četrtina predšolskih otrok dosega priporočila Ameriškega združenja za šport in športno vzgojo (National Asso-

\footnotetext{
${ }^{1}$ Nizka intenzivnost - gimnastične vaje, hoja pri o,4 m/s.

${ }^{2}$ Gibalna neaktivnost: ležanje s poslušanjem, ležanje, risanja, branje.

${ }^{3}$ Srednja intenzivnost: Hitra hoja pri o,8 m/s, lahkoten tek pri 1,2 m/s.

${ }^{4}$ Visoka intenzivnost: Tek pri 2-2,4 m/s, skiping, žabji poskoki.
} 
ciation of Sport and Physical Education 2009). Študije, ki preučujejo gibalno neaktivnost otrok med prvim in tretjim letom, kažejo, da otroci večji del budnega časa preživijo gibalno neaktivno (Vale idr. 2010; Johanssson idr. 2015; Carson idr. 2019) in pred ekrani (Vandewater idr. 2007; Zimmerman, Christakis in Meltzoff 2007), zato jih ogrožajo razvojne zamude in slabše splošno zdravstveno stanje (Kipling Webster, Martin in Staiano 2019). E. Johansson idr. (2015) navajajo, da dve leti stari otroci preživijo le $11 \%$ dnevnega časa v srednji in visoki intenzivnosti ter kar $55 \%$ časa gibalno neaktivno.

Predšolski otroci lahko dnevno v vrtcu preživijo od štiri pa vse do devet ur; prav zato ima vrtec pomembno vlogo pri oblikovanju otrokovih zdravih življenjskih navad, med katere vključujemo tudi gibalno aktivnost (Benjamin idr. 2008). Vsakodnevno vključevanje gibalne aktivnosti v obstoječi kurikulum vrtcev je učinkovita strategija za povečanje količine in intenzivnosti gibalne aktivnosti otrok v času vrtca (Trost idr. 2002). Pred samo izvedbo intervencijskega programa je nujno celovito poznavanje vzorcev gibalne aktivnosti posamezne starostne skupine otrok, saj le tako lahko zasnujemo učinkovit program za povečanje gibalne aktivnosti in zmanjšanje gibalne neaktivnosti otrok.

V zadnjem času je objavljenih kar nekaj študij, $v$ katerih so merili gibalno aktivnost z merilnikom pospeška in preučevali znotrajdnevne (Verbestel 2011; Van Cauwenberghe idr. 2012; Grønholt Olesen idr. 2014; Hesketh, Griffin in van Sluijs 2015; Brasholt idr. 2013) ter meddnevne (Verbestel idr. 2011; Van Cauwenberghe idr. 2012; Andersen idr. 2017; Grønholt Olesen idr. 2014; Hesketh idr. 2015; Brasholt idr. 2013; Vanderloo in Tucker 2015; Volmut 2014; Metcalf idr. 2002; Trost idr. 2000; Bringolf-Isler idr. 2009; Riddoch idr. 2007; Hardman, Horne in Rowlands 2009; Trayers idr. 2006; Treuth idr. 2005) razlike $v$ količini in intenzivnosti gibalne aktivnosti predšolskih otrok. Ugotovitve teh študij niso enotne, saj rezultati nekaterih kažejo, da so predšolski otroci gibalno aktivnejši med koncem tedna (Metcalf idr. 2002; Trost idr. 2000), druge kažejo na večjo aktivnost med tednom (Bringolf-Isler idr. 2009; Riddoch idr. 2007; Hardman, Horne in Rowlands 2009; Brasholt idr. 2013; Grønholt Olesen idr. 2014; Verbestel idr. 2011) Oz. da med tednom in koncem tedna razlik v gibalni aktivnosti ni (Trayers idr. 2006; Treuth idr. 2005). Primerjavo med dopoldanskim in popoldanskim časom je opravila T. Volmut (2014) na slovenskih predšolskih otrocih, starih pet let, in ugotovila, da imajo nižjo količino gibalne aktivnosti $v$ dopoldanskem času kot $v$ popoldanskem, ki ga preživijo $v$ domačem okolju. Njene ugotovitve so potrdili tudi L. Grønholt Olesen idr. (2014), in sicer da imajo danski predšolski otroci, stari pet in šest let, večjo količino gibalne aktivnosti v dopoldanskem času, ki ga preživijo v vrtcu. Večina 
študij se nanaša na pet- in šestletne predšolske otroke, medtem ko nismo zasledili podatkov za mlajše otroke, tj. med prvim in tretjim letom starosti.

Cilj naše raziskave je preučiti gibalno aktivnost in neaktivnost otrok med prvim in tretjim letom starosti ter povezanost znotrajdnevne (dopoldne in popoldne) in mednevne (teden in konec tedna) variabilnosti gibalne aktivnosti.

\section{Metode dela}

\section{Vzorec}

V raziskavo so bili vključeni predšolski otroci od prvega do tretjega leta starosti iz treh različnih slovenskih vrtcev. Skupno število sodelujočih otrok je bilo 26 , vendar smo dva otroka iz raziskave izključili, saj merilnika pospeška nista nosila zadostno količino časa in tako njunih podatkov nimamo za veljavne. $\checkmark$ nadaljnjo obdelavo smo vzeli podatke 24 otrok (11 dečkov, 13 deklic), povprečno starih 2,0 $\pm 0,6$ let. Vzorec je bil neslučajnosten in namensko izbran. Pred raziskavo so starši otrok podpisali pisno soglasje za sodelovanje $v$ raziskavi.

\section{Potek raziskave}

Raziskava je potekala aprila in maja 2015. Pred pričetkom smo vodstvo vrtcev prosili za sodelovanje pri raziskavi. Po odobritvi vodstva smo staršem razložili cilje in metode raziskave ter pridobili pisna soglasja. Meritve smo izvedli enkrat, presečno. Po predhodnem dogovoru s starši smo otrokom v vtrcu namestili merilnik pospeška. Staršem otrok smo izročili navodila ter jim na kratko razložili, kako z napravo ravnamo. Starši so otrokom nameščali (zjutraj) in odstranjevali (zvečer) merilnik pospeška skozi vseh pet dni merjenja.

\section{Pripomočki}

Gibalno aktivnost vsakega otroka smo zajemali z merilnikom pospeška (enoosni merilnik pospeška Actigraph GT1M, Actigraph LLC, ZDA) pet zaporednih dni, in sicer tri dni med tednom in dva dni med koncem tedna (od srede do nedelje). Merilnik pospeška, s katerim smo izmerili količino in intenzivnost gibalne aktivnosti, so otroci nosili okoli pasu na desnem boku - $v$ višini popka. Med spanjem, tuširanjem in kopanjem merilnika otroci niso nosili. Merilniki so merili v 15-sekundni časovni epohi, to je časovni interval, v katerem merilnik pospeška zbira in shranjuje podatke (Rowlands 2007). Upoštevali smo le podatke med osmo uro zjutraj in osmo uro zvečer. Pred nadaljnjo obdelavo smo vse zaporedne ničle, ki so bile daljše od 20 minut, izločili (Cain idr. 2013; Esliger idr. 2005). Za veljavno smo dnevno merjenje šteli le $v$ primeru vsaj 
šesturnega ( $50 \%$ ) posnetka gibanja, kar je več kot priporočajo T. Hinkley idr. (2012). Za veljaven posnetek je moral otrok imeti vsaj tri veljavne dni merjenja oz. dva dni med tednom in en dan med koncem tedna (Cliff, Reilly in Okelly 2009). Upoštevali smo naslednje meje med posameznimi intenzivnostmi: gibalna neaktivnost: <192 sunkov na minuto (cpm); nizka intenzivnost gibalne aktivnosti: 193-1673 cpm, srednja in visoka intenzivnost gibalne aktivnosti: $>1673 \mathrm{cpm}$ (Trost idr. 2012).

\section{Obdelava podatkov}

Vse statistične analize smo opravili s programom SPSS. Podatki so v preglednicah prikazani s povprečno vrednostjo in standardnim odklonom. S $t$ testom za odvisne vzorce smo preučili, ali obstajajo razlike med količino in vsemi fenotipi intenzivnosti gibalne aktivnosti v času vrtca (od 8.00 do 16.00) in po njem (od 16.00 do 20.00) ter med tednom in koncem tedna. S pomočjo Pearsonove korelacije smo preverili, ali obstaja povezava med posameznimi fenotipi intenzivnosti in celotno gibalno aktivnostjo med tednom ter med koncem tedna in ali obstaja povezava med dopoldanskim in popoldanskim časom (le podatki od srede do petka). Vse odločitve smo sprejemali pri stopnji tveganja $p<0,05 . V$ primeru značilnih razlik povprečnih vrednosti smo poročali še o velikosti efekta teh razlik (ES) in v primeru značilnih povezav še o determinacijskem koeficientu $\left(r^{2}\right)$. Velikost efekta smo opredelili kot majhno $(>0,2)$, srednjo $(0,2-0,8)$ in veliko $(<0,8)$.

\section{Rezultati}

Otroci, ki so dosegali kriterije (minimalno nošenje merilnika pospeška dva dni med tednom in en dan med koncem tedna ter vsaj $50 \%$ dnevnega opazovanega časa) in bili vključeni v nadalnjo analizo, so merilnik pospeška $v$ povprečju nosili $78 \%$ dnevnega časa. Le 13 otrok $(54,2 \%)$ je v povprečju doseglo vsaj 60 minut srednje in visoke intenzivnosti. Le 5 otrok (21\%) pa je doseglo omenjena priporočila $v$ vsakem dnevu nošenja merilnika pospeška.

Preglednica 1 prikazuje skupno količino in čas posameznega fenotipa intenzivnosti tedenske (od srede do vključno nedelje) gibalne aktivnosti, ki je prikazana v sunkih na minuto. Prikazana sta tudi količina in odstotek časa gibalne aktivnosti posameznega fenotipa intenzivnosti med tednom (od srede do petka) in med koncem tedna (od sobote do nedelje). Otroci med petdnevnim nošenjem merilnika pospeška preživijo v povprečju $54 \%$ dnevnega časa gibalno neaktivno, $36 \%$ dnevnega časa so deležni nizke intenzivnosti ter le 9,9\% časa so deležni srednje in visoke intenzivnosti gibalne aktivnosti. Rezultati kažejo, da ni razlik med količino ter odstotkom časa srednje in visoko 
Preglednica 1 Skupna tedenska gibalna aktivnost in primerjava gibalne aktivnosti ter posameznih intenzivnosti med tednom in koncem tedna

\begin{tabular}{lrrrr}
\hline Postavka & Skupna GA & $\begin{array}{r}\text { GA med } \\
\text { tednom }\end{array}$ & $\begin{array}{r}\text { GA med } \\
\text { koncem tedna }\end{array}$ & $\begin{array}{r}p \text { (teden/konec } \\
\text { tedna) (ES) }\end{array}$ \\
\hline Skupna količina GA & $571 \pm 200$ & $558 \pm 231$ & $584 \pm 184$ & 0,542 \\
Gibalna neaktivnost & $389 \pm 43$ & $55 \pm 7$ & $51 \pm 9$ & $0,017(0,57)$ \\
Nizka intenzivnost GA & $260 \pm 28$ & $35 \pm 4$ & $38 \pm 5$ & $0,002(0,75)$ \\
Srednja in visoka & $71 \pm 25$ & $10 \pm 4$ & $9 \pm 3$ & 0,895 \\
intenzivnost GA & & & & \\
\hline
\end{tabular}

Opombe ES-velikost efekta.

Preglednica 2 Skupne gibalne aktivnosti in intenzivnosti posameznih gibalnih aktivnosti med časom vrtca in časom po vrtcu

\begin{tabular}{lrrr}
\hline Postavka & GA v času vrtca & GA po vrtcu & $p(E S)$ \\
\hline Skupna količina GA & $491 \pm 172$ & $692 \pm 461$ & $0,026(1,16)$ \\
Gibalna neaktivnost & $58 \pm 8$ & $50 \pm 8$ & $<0,001(1,00)$ \\
Nizka intenzivnost GA & $33 \pm 5$ & $39 \pm 5$ & $<0,001(1,20)$ \\
Srednja in visoka intenzivnost GA & $9 \pm 4$ & $11 \pm 6$ & $0,024(0,50)$ \\
\hline
\end{tabular}

Opombe ES - velikost efekta. V analizo so zajeti le podatki od srede do petka.

intenzivne gibalne aktivnosti med tednom in koncem tedna. Otroci so med tednom deležni $4 \%$ več gibalne neaktivnosti kot $(p=0,017 ; E S=0,57)$ med koncem tedna, medtem ko so med koncem tedna deležni $3 \%$ več časa nizke intenzivnosti gibalne aktivnosti kot med tednom $(p=0,002 ; E S=0,75)$. Kot vidimo, je velikost efekta na gibalno neaktivnost in nizko intenzivnost gibanja srednja.

$\checkmark$ preglednici 2 so prikazani rezultati količine in posameznega fenotipa intenzivnosti gibalne aktivnosti otrok v času, ki ga preživijo v vrtcu (od 8. do 16. ure), in v času, ki ga preživijo v domačem okolju (od 16. do 20. ure). Rezultati kažejo, da otroci v času, ki ga preživijo v domačem okolju, dosežejo za $41 \%$ večjo količino gibalne aktivnosti $(p=0,026 ; E S=1,16)$, za $8 \%$ manj gibalne neaktivnosti $(p<0,001 ; E S=1,00)$, za $6 \%$ več nizke intenzivnosti gibalne aktivnosti ( $p<0,001 ; E S=1,20)$ in za $2 \%$ več srednje in visoke intenzivnosti gibalne aktivnosti $(p=0,024 ; E S=0,50)$ kot v času, ki ga preživijo v vrtcu. Kot vidimo, je velikost efekta na vse fenotipe gibalne aktivnosti srednja do velika.

Preglednica 3 prikazuje povezanost gibalne aktivnosti med tednom in koncem tedna. Rezultati kažejo srednjo moč pozitivne povezanosti celotne količine gibalne aktivnosti otrok $(r=0,688 ; p<0,001)$, časa gibalne neaktivnosti $(r=0,433 ; p>0,039)$ in časa nizke intenzivnosti $(r=0,500 ; p=0,015)$ gibalne aktivnosti. In sicer čas med tednom razloži med 19 in $47 \%$ variance povezano- 
Preglednica 3 Pearsonova povezanost $(r)$ fenotipov gibalne aktivnosti med tednom in koncem tedna

\begin{tabular}{lrr}
\hline Postavka & Pearsonova $r\left(r^{2}\right)$ & $p$ \\
\hline Skupna količina GA & $0,688(47 \%)$ & $<0,001$ \\
Gibalna neaktivnost & $0,433(19 \%)$ & 0,039 \\
Nizka intenzivnost GA & $0,500(25 \%)$ & 0,015 \\
Srednja in visoka intenzivnost GA & 0,262 & 0,227 \\
\hline
\end{tabular}

Preglednica 4 Pearsonova povezanost $(r$ ) fenotipov gibalne aktivnosti med dopoldanskim in popoldanskim časom.

\begin{tabular}{lrr}
\hline Postavka & Pearsonova $r\left(r^{2}\right)$ & $p$ \\
\hline Skupna količina GA & $0,448(20 \%)$ & 0,028 \\
Gibalna neaktivnost & 0,395 & 0,056 \\
Nizka intenzivnost GA & 0,208 & 0,330 \\
Srednja in visoka intenzivnost GA & $0,543(29 \%)$ & 0,006 \\
\hline
\end{tabular}

sti. V primerjavi časa srednje in visoke intenzivnosti gibalne aktivnosti nismo ugotovili povezanosti.

Preglednica 4 prikazuje povezanost gibalne aktivnosti med časom, ki so ga otroci preživeli v vrtcu, in časom, ki so ga preživeli v domačem okolju, in sicer le za obdobje od srede do petka. Rezultati kažejo srednjo moč pozitivne povezanosti celotne gibalne aktivnosti $(r=0,448 ; p=0,028)$ in časa srednje ter visoke intenzivnosti gibalne aktivnosti $(r=0,543 ; p=0,006)$. In sicer dnevni čas razloži med $20 \%$ in $29 \%$ variance povezanosti. V času nizke gibalne intenzivnosti nismo ugotovili povezanosti. Pravo tako smo ugotovili zgolj trend povezanosti časa gibalne neaktivnosti $(r=0,395 ; p=0,056)$.

\section{Razprava}

Cilj našega prispevka je bil z merilnikom pospeška izmeriti gibalno aktivnost in gibalno neaktivnost otrok med prvim in tretjim letom starosti ter preučiti znotrajdnevno in mednevno variabilnost gibalne aktivnosti. Ugotovili smo, da so otroci $46 \%$ dnevnega časa gibalno aktivni, tako $v$ nizki kot tudi $v$ srednji in visoki intenzivnosti gibalne aktivnosti. Žal pa kar $54 \%$ dnevnega časa preživijo gibalno neaktivno. V skladu z našimi rezultati je tudi raziskava E. Johansson idr. (2015), ki navajajo, da dve leti stari norveški otroci več kot $50 \%$ dnevnega časa preživijo gibalno aktivno.

Rezultate študij, ki preučujejo gibalno atkivnost šolskih otrok, velikokrat primerjamo s priporočili Svetovne zdravstvene organizacije (World Health Organization 2010). Slednja pravijo, naj bodo otroci in mladostniki med 5. 
in 17. letom deležni vsaj 60 minut srednje in visoke intenzivnosti na dan. Strokovnjaki iz različnih držav (Tremblay idr. 2012; Department of Health and Aging 2010; National Association of Sport and Physical Education 2009) so razvili priporočila gibalne aktivnosti za otroke, mlajše od pet let. Slednja pravijo, naj bodo predšolski otroci najmanj 90 minut dnevno gibalno aktivni, tako v nizki kot v visoki intenzivnosti. Priporočila gibalne aktivnosti za vrtčevske otroke ne omenjajo, koliko časa na dan naj bodo deležni posameznega fenotipa intenzivnosti, kot to omenjajo priporočila gibalne/športne aktivnosti za otroke, starejše od pet let, in mladostnike. Prav zato je nemogoče primerjati naše rezutlate $s$ priporočili gibalne aktivnosti za vrtčevske otroke, saj smo naše rezultate primerjali s priporočili Svetovne zdravstvene organizacije (World Health Organization 2010), ki priporoča, naj bodo otroci deležni vsaj 60 minut srednje in visoke intenzivnosti gibalne aktivnosti na dan. Večina študij, ki prečuje gibalno aktivnost predšolskih otrok, poroča, da znaten delež otrok ne izpolnjuje splošnih priporočil World Health Organization (2010; Hnatiuk idr. 2014), ampak da večji del dneva preživijo gibalno neaktivno (Aadland in Johannessen 2015; Van Cauwenberghe idr. 2012; Reilly 2008; Trucker 2008; Kuzik idr. 2015; Johanssson idr. 2015; Carson idr., 2019). Ugotovili smo, da so otroci deležni 36,4 do 128,3 minut dnevne srednje in visoke intenzivnosti gibalne aktivnosti, medtem pa kar 314,2 do 460,3 minut dnevne gibalne neaktivnosti. Do poodobnih ugotovitev so prišli tudi Andersen idr. (2017), ki poročajo, da so norveški predšolski otroci, stari tri in štiri leta, deležni od 16 do 116 dnevnih minut v srednji in visoki gibalni intenzivnosti, gibalno neaktivni pa so od 150 do 390 minut. Glede na te podatke lahko zaključimo, da je le 13 (54\%) naših otrok doseglo priporočila Svetovne zdravstvene organizacije, ki so sicer priporočena za pet- in večletne otroke. Poudariti pa gre tudi, da le pet otrok (21\%) sistematično vsakodnevno dosega ta priporočila. Vsa priporočila (Tremblay idr. 2012; Department of Health and Aging 2010; National Association of Sport and Physical Education 2009) za predšolske otroke poudarjajo večurno dnevno gibalno aktivnost, ki je razporejena skozi cel dan ter vključuje različne gibalne naloge in pripomočke, saj lahko otroci le tako razvijajo svoje gibalne sposobnosti in spretnosti.

T. Volmut (2014) v svoji študiji, v katero so bili vključeni slovenski otroci med petim in osmim letom starosti, navaja, da ni razlik med tednom in koncem tedna v celotni gibalni aktivnosti, gibalni neaktivnosti ter srednji in visoki intenzivnosti gibalne aktivnosti. Gibalna aktivnost otrok našega vzroca je bila med tednom in koncem tedna skoraj enaka, saj smo ugotovili, da ni razlik v količini gibalne aktivnosti ter deležom časa srednje in visoke intenzivnosti gibalne aktivnosti. Medtem pa lahko opazimo, da imajo otroci med tednom večjo gi- 
balno neaktivnost in manjši delež časa nizke intenzivnosti gibalne aktivnosti kot med koncem tedna. Ugotovili smo tudi povezanost količine gibalne aktivnosti, gibalne neaktivnosti in nizke intenzivnosti gibalne aktivnosti mlajših predšolskih otrok med tednom in koncem tedna, vendar ne moremo postavljati trditev o vplivu.

Splošni podatki Statističnega urada Republike Slovenije navajajo, da $64 \%$ otrok med prvim in drugim letom starosti med tednom obiskuje vrtce. Vsakdanji vrtčevski urnik omogoča, da so otroci v dopoldanskem času prosto ali organizirano gibalno aktivni na prostem ali v zaprtih prostorih. S. E. Benjamin idr. (2008) poudarjajo, da imajo vrtci pomembno vlogo pri vzpostavljanju vsakodnevnih gibalnih navad in zmanjševanju sedentarnih navad. Kljub temu pa rezultati študij kažejo, da temu ni tako, saj navajajo, da so otroci v času, ki ga preživijo v vrtcih, deležni preveč gibalne neaktivnosti ter malo časa srednje in visoke intenzivnosti (Vanderloo idr. 2014; Byun idr. 2013; Reilly 2010). Rezultati naše študije se ujemajo z ugotovitvami predhodno objavljenih študij (Vanderloo idr. 2014; Byun idr. 2013; Reilly 2010), saj kažejo, da imajo otroci večji delež časa gibalne neaktivnosti nižjo celotno količino gibalne aktivnosti, nižji delež časa nizke ter srednje in visoke intenzivnosti gibalne aktivnosti v času vrtca kot po njem. Ugotovili smo tudi povezanost količine gibalne aktivnosti, gibalne neaktivnosti ter srednje in visoke intenzivnosti gibalne aktivnosti mlajših predšolskih otrok v času, ki ga preživijo v vrtcu, in času, ki ga preživijo v domačem okolju, vendar ne moremo postavljati trditev o vplivu.

Zavedati se moramo, da je vključevanje gibalne aktivnosti v obstoječi kurikulum vrtcev učinkovita strategija za povečanje količine gibanja (Trost idr. 2002) in zmanjšanje gibalne neaktivnosti. Gibalna aktivnost otrok v času vrtca je odvisna od interesa, motivacije in strokovnega znanja vzgojiteljic glede izvajanja gibalnih aktivnosti. Ne smemo zanemariti tudi dobrih materialnih in prostorskih dejavnikov, ki so poleg dobrega in usposobljenega kadra pomembni pri uresničevanju kakovostnih gibalnih aktivnosti v vrtcu, katerih cilj je celosten razvoj otroka (Zajec 2009). J. Zajec (2009) v svoji doktorski disertaciji ugotavlja, da imajo le redki vrtci ustrezne posebne prostore in športne pripomočke za izvajanje gibalnih aktivnosti. Vzgojitelji najpogosteje izvajajo gibalne aktivnosti ravno $v$ manj primernih prostorih, in sicer vigralnicah, nato $\checkmark$ večnamenskih prostorih, na hodnikih, $v$ športni igralnici in drugje.

Nižjo gibalno aktivnost otrok med prvim in tretim letom starosti $v$ času vrtca lahko pripisujemo tudi dolžini dnevnega spanja. Več kot $90 \%$ otrok (Blair idr. 2012) te starosti čez dan še vedno povprečno spi od ene do treh ur (Pantley 2003; Blair idr. 2012). Zato menimo, da bi bilo potrebno v prihodnjih študijah izključiti čas dnevnega spanja, saj bi le tako dobili realnejše podatke 
o gibalni aktivnosti v času, ki ga otroci preživijo v vrtcu. Menimo, da lahko razlog za nižjo gibalno aktivnost mlajših predšolskih otrok $v$ času, ki ga preživijo $v$ vrtcu, pripisujemo tudi mnenju vzgojiteljic, da otroci v tej starosti ne zmorejo daljših in zahtevnejših aktivnosti. $V$ našo raziskavo je zajet le majhen delež mlajših predšolskih otrok, zato rezultatov ne moremo posplošiti, predlagamo pa, da se v prihodnje naredi obširnejša študija, katere namen bo preučiti gibalne navade otrok med prvim in tretjim letom starosti.

Dobljeni rezultati zagotavljajo boljše razumevanje vzorcev gibalne aktivnosti in gibalne neaktivnosti najmlajših predšolskih otrok. Le $z$ dobrim poznavanjem vzorcev gibalne aktivnosti in neaktivnosti lahko načrtujemo ter izvajamo gibalne intervencije, katerih namen je povečati gibalno aktivnost otrok in zmanjšati gibalno neaktivnost najmlajših predšolskih otrok.

\section{Literatura}

Aadland, E., in K. Johannessen. 2015. »Agreement of Objectively Measured Physical Activity and Sedentary Time in Preschool Children."Preventive Medicine Reports 21 (2): 635-639.

Andersen, E., J. Borch-Jenssen, S. Øvreås, H. Ellingsen, K. A. Jørgensen in T. Moser. 2017. »Objectively Measured Physical Activity Level and Sedentary Behavior in Norwegian Children during a Week in Preschool.» Preventive Medicine Reports 7:130-135.

Benjamin, S. E., A. Cradock, E. M. Walker, M. Slining in M. W. Gillman. 2008. »Obesity Prevention in Child Care: A Review of U.S. State Regulations."BMC Public Health 30 (8): 188.

Blair, S. N., Y. Cheng in S. J. Holder. 2001. »/s Physical Activity or Physical Fitness More Important in Defining Healt Benefits? « Medicine and Science in Sports and Exercise 33 (6): 379-399.

Blair, P. S., J. S. Humphreys, P. Gringras, S. Taheri, N. Scott, A. Emond, J. Henderson in P. J. Fleming. 2012. "Childhood Sleep Duration and Associated Demographic Characteristics in an English Cohort." SLEEP 35 (3): 353-360.

Brasholt, M., B. Chawes, E. Kreiner-Møller, S. Vahlkvist, M. Sinding in H. Bisgaard. 2013. »Objective Assessment of Levels and Patterns of Physical Activity in Preschool Children.«Pediatric Research 74 (3): 333-338.

Bringolf-Isler, B., L. Grize, U. Mäder, N. Ruch, F. H. Sennhauser in C. BraunFahrländer. 2009. "Assessment of Intensity, Prevalence and Duration of Everyday Activities in Swiss School Children: A Cross-Sectional Analysis of Accelerometer and Diary Data.« International Journal of Behavioral Nutrition and Physical Activity 6 (50). https://www.doi.org/10.1186/1479-5868-6 $-50$

Byun, W., S. Blair in R. Pate. 2013. „Objectively Measured Sedentary Behavior in Preschool Children: Comparison between Montessori and Traditional Pre- 
schools. International Journal of Behavioral Nutrition and Physical Activity 10:2-7.

Cain, K. L., J. F. Sallis, T. L. Conway, D. Van Dyck in L. Calhoon. 2013. »Using Accelerometers in Youth Physical Activity Studies: A Review of Methods. "Journal of Physical Activity and Health 10 (3): 437-450.

Canadian Society of Exercise Physiology. 2015. »Canadian Sedentary Behaviour Guidelines for the Early Years (o-4 Years).« http://www.csep.ca/CMFiles/ Guidelines/CSEP_SBGuidelines_early-years_en.pdf

Cardon, G., E. Van Cauwenberghe in I. De Bourdeaudhuij. 2011. »What Do We Know about Physical Activity in Infancy and Toddlers: A Review of the Literature and Future Research Directions." Science and Sports 26:127-130.

Carson, V., E.-Y. Lee, K. D. Hesketh, S. Hunter, N. Kuzik, M. Predy, R. E. Rhodes, C. M. Rinaldi, J. C. Spence in T. Hinkley. 2019. »Physical Activity and Sedentary Behavior Across Three Time-Points and Associations with Social Skills in Early Childhood."BMC Public Health 19 (1): 27.

Certain, L. K., in R. S. Kahn. 2002. »Prevalence Correlates and Trajectory of Television Viewing among Infants and Toddlers.« Pediatrics 109 (4): 634-642.

Cliff, D. P., J. J. Reilly in A. D. Okely. 2009. »Methodological Considerations in Using Accelerometers to Assess Habitual Physical Activity in Children Aged 0-5 Years." Journal of Science and Medicine in Sport 12 (5): 557-567.

Department of Health and Aging. 2010. Get up and Grow: Healthy Eating and Physical Activity for Early Childhood. Canberra: Australian Government.

Esliger, D. W., J. L. Copeland, J. D. Barnes in M. S. Tremblay. 2005. "Standardizing and Optimizing the Use of Accelerometer Data for Free-Living Physical Activity Monitoring. " Journal of Physical Activity and Health 2 (3): 366-383.

Grønholt Olesen, L., P. Lund Kristensen, M. Ried-Larsen, A. Grøntved in K. Froberg. K. 2014. »Physical Activity and Motor Skills in Children Attending 43 Preschools: A Cross-Sectional Study.« BMC Pediatrics 14:229. https://www .doi.org/10.1186/1471-2431-14-229

Hardman, C. A., P. J. Horne in A. V. Rowlands. 2009. „Children's PedometerDetermined Physical Activity During School-Time and Leisure-Time.« Journal of Exercise Science \& Fitness 7 (2): 129-134.

Hesketh, K. R., S. J. Griffin in E. M. F. van Sluijs 2015. »UK Preschool-Aged Children's Physical Activity Levels in Childcare and at Home: A Cross-Sectional Exploration. « International Journal of Behavioral Nutrition and Physical Activity 12:123.

Hinkley, T., E. O'Connell, A. D. Okely, D. Crawford, K. Hesketh in J. Salmon. 2012. »Assessing Volume of Accelerometry Data for Reliability in Preschool Children.« Medicine and Science in Sports and Exercise 44 (12): 2436-2441.

Hnatiuk, J. A., J. Salmon, T. Hinkley, A. D. Okely in S. Trost. 2014. »A Review of Preschool Children's Physical Activity and Sedentary Time Using Objective Measures."American Journal of Preventive Medicine 47 (4): 487-497. 
Janz, K. F., T. L. Burns in S. M. Levy. 2005. »Tracking of Activity and Sedentary Behaviors in Childhood: The lowa Bone Development Study.«American Joural of Preventive Medicine 29 (3): 171-178.

Johansson, E., M. Hagströmer, V. Svensson, A. Ek, M. Forssén, H. Nero in C. Marcus. 2015. »Objectively Measured Physical Activity in Two-Year-Old Children: Levels, Patterns and Correlates. International Journal of Behavioral Nutrition and Physical Activity 12:3. https://www.doi.org/10.1186/s12966 -015-0161-0

Kipling Webster, E., C. K. Martin in A. E. Staiano. 2019. »Fundamental Motor Skills, Screen-Time, and Physical Activity in Preschoolers." Journal of Sport and Health Science 8 (2): 114-121.

Kriska, A. M., A. Saremi, R. L. Hanson, P. H. Bennett, S. Kobes, D. E. Williams in W. C. Knowler. 2003. »Physical Activity, Obesity, and the Incidence of Type 2 Diabetes in a High-Risk Population. « American Journal of Epiodemiology 158 (7): 669-675.

Kuzik, N., D. Clark, N. Ogden, V. Harber in V. Carson. 2015. »Physical Activity and Sedentary Behaviour of Toddlers and Preschoolers in Child Care Centres in Alberta, Canada."Canadian Journal of Public Health 106 (4): e178-e183.

LeBlanc, A. G., J. C. Spence, V. Carson, S. Connor Gorber, C. Dillman, I. Janssen, M. E. Kho, J. A. Stearns, B. W. Timmons in M. S. Tremblay. 2012. "Systematic Review of Sedentary Behaviour and Health Indicators in the Early Years (Aged o-4 Years).«Applied Physiology, Nutrition, and Metabolism 37 (4): 753772.

Metcalf, B. S., J. S. H. Curnow, C. Evans, L. D. Voss in T. J. Wilkin. 2002. »Technical Reliability of the CSA Activity Monitor: The Early Bird Study." Medicine and Science of Sports and Exercise 34 (9): 1533-1537.

National Association for Sport and Physical Education. 2009. Active Start: A Statement of Physical Activity Guidelines for Children from Birth to Age 5. 2. izd. Sewickley, PA: American Alliance for Health, Physical Education, Recreation, and Dance.

Pantley, E. 2003. Otroško spanje - brez joka v sanje. Radovljica: Didakta.

Pišot, R., in J. Planinšec. 2005. Struktura motorike v zgodnjem otroštvu: motorične sposobnosti v zgodnjem otroštvu v interakciji z ostalimi dimenzijami psihosomatičnega statusa otroka. Koper: Annales.

Reilly, J. J. 2008. »Physical Activity, Sedentary Behaviour and Energy Balance in the Preschool Child: Opportunities for Early Obesity Prevention. "The Proccedings of the Nutrition Society 67 (3): 317-325.

- 2010. "Low Levels of Objectively Measured Physical Activity in Preschoolers in Child Care.« Medicine and Science in Sports and Exercise 42 (3): 502-507.

Riddoch, C. J., L. Bo Andersen, N. Wedderkopp, M. Harro, L. Klasson-Heggebø, L. B. Sardinha in A. B. Cooper. 2004. »Physical Activity Levels and Patterns 
of 9- and 15-Yr-Old European Children. «Medicine and Science in Sports and Exercise 36 (1): 86-92.

Riddoch, C. J., C. Mattocks, K. Deere, J. Saunders, J. Kirkby, K. Tilling, S. D. Leary, S. N. Blair in A. R. Ness. 2007. "Objective Measurement of Levels and Patterns of Physical Activity." Archives of Disease in Childhood 92 (11): 963-969.

Rowlands, A. V. 2007. »Accelerometer Assessment of Physical Activity in Children: An Update.« Pediatric Exercise Science 19 (3): 252-266.

Timmons, B. W., P. J. Naylor in K. A. Pfeiffer. 2007. »Physical Activity for Preschool Children: How Much and How? «Canadian Journal of Pubblic Health 98 (S2): 122-134.

Trayers, T., A. R. Cooper, C. J. Riddoch, A. R. Ness, K. R. Fox, R. Deem in D. A. Lawlor. 2006. „Do Children from an Inner City British School Meet the Recommended Levels of Physical Activity?« Archives of Disease in Childhood 91 (2): 175-176.

Treuth, M. S., N. Hou, D. R. Young in M. Maynard. 2005. »Accelerometry-Measured Activity or Sedentary Time and Overweight in Rural Boys and Girls." Obesity Research 13 (9): 1606-1614.

Tremblay, M. S., A. G. Leblanc, V. Carson, L. Choquette, S. Connor Gorber, C. Dillman, M. Duggan idr. 2012. „Canadian Physical Activity Guidelines for the Early Years (Aged o-4 Years).« Applied Physiology, Nutrition, and Metabolism 37 (2): 345-356.

Trost, S. G., R. R. Pate, P. S. Freedson, J. F. Sallis in W. C. Taylor. 2000. »Using Objective Physical Activity Measures with Youth: How Many Days of Monitoring are Needed?« Medicine and Science in Sports and Exercise 32 (2): 426-431.

Trost, S. G., R. R. Pate, J. F. Salis, P. S. Freedson, W. C. Taylor, M. Dowda in J. Sirard. 2002. "Age and Gender Differences in Objectively Measured Physical Activity in Youth." Medicine and Science in Sports and Exercise 34 (2): 350-355.

Trost, S. G., B. S. Fees, S. J. Haar, A. D. Murray in L. K. Crowe. 2012. »Identification and Validity of Accelerometer Cut Points for Toddlers. «Obesity 20 (11): 23172319.

Tucker, P. 2008. „The Physical Activity Levels of Preschool-Aged Children: A Systematic Review.«Early Childhood Research Quarterly 23:547-558.

Vale, S., P. Silva, R. Santos, L. Soares-Miranda in J. Mota. 2010. „Compliance with Physical Activity Guidelines in Preschool Children. « Journal of Sports Science 28 (6): 603-608.

Vale, S., S. G. Trost, C. Rêgo, S. Abreu in J. Mota. 2015. »Physical Activity, Obesity Status, and Blood Pressure in Preschool Children. «The Journal of Pediatrics 167 (1): 98-102.

Van Cauwenberghe, E., R. A. Jones, T. Hinkley, D. Crawford in A. D. Okely. 2012. »Patterns of Physical Activity and Sedentary Behaviour in Preschool Children. «The International Journal of Behavioral Nutrition and Physical Activity 9:138. https://www.doi.org/10.1186/1479-5868-9-138 
Vanderloo, L. M., in P. Tucker. 2015. »An Objective Assessment of Toddlers' Physical Activity and Sedentary Levels: A Cross-Sectional Study.«BMC Public Health 15:969. https://www.doi.org/10.1186/s12889-015-2335-8

Vanderloo, L. M., P. Tucker, A. M. Johnson, M. M. van Zandvoort, S. M. Burke in J. D. Irwin. 2014. „The Influence of Centre-Based Childcare on Preschoolers' Physical Activity Levels: A Crosssectional Study.« International Journal of Environmental Research and Public Health 11:1794-1802.

Vandewater, E. A., V. J. Rideout, E. A. Wartella, X. Huang, J. H. Lee in M. S. Shim. 2007. »Digital Childhood: Electronic Media and Technology Use among Infants, Toddlers, and Preschoolers.«Pediatrics 119 (5): e1006-e6015.

Verbestel, V., E. Van Cauwenberghe, V. De Coen, L. Maes, I. De Bourdeaudhuij in G. Cardon. 2011. »Within- and Between-Day Variability of Objectively Measured Physical Activity in Preschoolers. « Pediatric Exercise Science 23 (3): 366-378.

Volmut, T. 2014. »Z merilnikom pospeška izmerjena gibalna/športna aktivnost mlajših otrok in analiza izbranih intervencij.» Doktorska disertacija, Univerza na Primorskem.

Zajec, J. 2009. »Povezanost športne dejavnosti predšolskih otrok in njihovih staršev z izbranimi dejavniki zdravega načina življenja.« Doktorska disertacija, Univerza v Ljubljani.

Zimmerman, F., D. A. Christakis in A. N. Meltzoff. 2007. »Television and DVD/Video Viewing in Children Younger than 2 Years." Archives of Pediatrics and Adolescent Medicine 161 (5): 473-479.

World Health Organization. 2010. Global Recommendations on Physical Activity for Health. Geneva: World Health Organization.

\section{Accelerometer Assessed Physical Activity and Inactivity of Children between the First and Third Years of Age}

Objective: The aim of our study is to examine the physical activity and inactivity of children between the first and third year of age, and to study the correlation of the intra-day and inter-day variability of physical activity phenotypes. Methods: Twenty-four children, between the first and third year of age, from three Slovenian kindergartens, wore an accelerometer for five consecutive days. We compared the phenotypes of the intensity of the physical activity during the time of the kindergarten ( $9 \mathrm{am}-4 \mathrm{pm}$ ) and after (16-20 pm), and between the week (Wednesday-Friday) and the end of the week (Saturday-Sunday). Results: On average, children reached $571 \pm 200$ counts per minute, of which 389 \pm 43 minutes were inactive, with a moderate and vigorous physical activity of $71 \pm 25$ minutes. During the week, they were $4 \%$ more physically inactive ( $p=$ $0.017 ; E S=0.57)$ and $3 \%$ less time in low intensity physical activity $(p=0.002$; $E S=0.75)$ as during the weekend. After the kindergarten they were $41 \%$ more physically active $(p=0.026, E S=1.16), 8 \%$ less inactive $(p<0.001, E S=1.00), 6 \%$ 
less time in low intensity of physical activity $(p<0.001, E S=1.20)$ and for $2 \%$ more in modetate to vigorous physical activity $(p=0.024, E S=0.50)$. We found also a correlation between the total physical activity during the week and the weekend $(r=0.688, p<0.001)$, as well as during the kindergarten time and afterwards $(r=0.448, p=0.028)$. Conclusion: The study provides important physical activity data of the youngest, one to three year olds, children who indicate the correlations of physical activity at different times of the day and between days, which should be taken into account when designing children's physical programs.

Keywords: accelerometer, kindergarten, week, weekend, morning, afternoon 